Article

\title{
Hechtia glomerata Zucc: Phytochemistry and Activity of Its Extracts and Major Constituents Against Resistant Bacteria
}

\author{
Tommaso Stefani ${ }^{1}$, Elvira Garza-González ${ }^{2}$, Verónica M. Rivas-Galindo ${ }^{3}$, \\ María Yolanda Rios 4(D), Laura Alvarez ${ }^{4}$ (D) and María del Rayo Camacho-Corona ${ }^{1, *(D)}$ \\ 1 Universidad Autónoma de Nuevo León, Facultad de Ciencias Químicas, Av. Universidad S/N, \\ Ciudad Universitaria, CP San Nicolás de los Garza 66451, Nuevo León, Mexico; tstefani854@gmail.com \\ 2 Universidad Autónoma de Nuevo León, Servicio de Gastroenterología Hospital Universitario Dr. José \\ Eleuterio González, Av. Gonzalitos y Madero S/N, Col. Mitras Centro, CP Monterrey 64460, Nuevo León, \\ Mexico; elvira_garza_gzz@yahoo.com \\ 3 Universidad Autónoma de Nuevo León, Facultad de Medicina, Av. Madero S/N, Col. Mitras Centro, \\ CP Monterrey 64460, Nuevo León, Mexico; veronica.rivasgl@uanl.edu.mx \\ 4 Universidad Autónoma del Estado de Morelos, Centro de Investigaciones Químicas IICBA, \\ Av. Universidad 1001, Col. Chamilpa, Cuernavaca, Morelos 62209, Mexico; myolanda@uaem.mx (M.Y.R.); \\ lalvarez@uaem.mx (L.A.) \\ * Correspondence: maria.camachocn@uanl.edu.mx; Tel.: +52-8183294000 (ext. 3414); Fax: +52-8183529025
}

Received: 13 July 2019; Accepted: 17 September 2019; Published: 21 September 2019

\begin{abstract}
Hechtia glomerata Zucc. is used both as a source of food and in ethnomedicine to treat various diseases derived from bacterial infections such as bronchitis, laryngitis, nephritis, whooping cough, urethritis, and sepsis. There are no previous reports about its chemistry and biological activities. Therefore, the aims of this study were to identify components from organic and aqueous extracts of H. glomerata and test the extracts and major isolate compounds against resistant bacteria. Hexane, $\mathrm{CHCl}_{3} / \mathrm{MeOH}$, and aqueous extracts were prepared and analyzed by different chromatographic techniques. Structural elucidation was carried out by NMR spectroscopy and X-ray diffraction. The antibacterial activities of extracts, phytochemicals, and semisynthetic derivatives against resistant bacteria were determined by the broth micro-dilution method. From the hexane extract nonacosane (1), hexatriacontanyl stearate (2), hexacosanol (3), oleic acid (4), and $\beta$-sitosterol (5) were isolated and characterized. From the $\mathrm{CHCl}_{3} / \mathrm{MeOH}$ extract, $p$-coumaric acid (6), margaric acid (7), caffeic acid (8), daucosterol (9), and potassium chloride (10) were isolated and characterized. A total of 58 volatile compounds were identified by GC-MS from the hexane extract and two solids were isolated from the $\mathrm{CHCl}_{3} / \mathrm{MeOH}$ extract. The UPLC-QTOF-MS analysis of the aqueous extract allowed the identification of 55 polar compounds. Hexane and aqueous extracts showed antibacterial activity against ESBL Escherichia coli, and three strains of Klebsiella pneumoniae ESBL, NDM-1 +, and OXA-48 with MIC values of $500 \mu \mathrm{g} / \mathrm{mL}$. The $\mathrm{CHCl}_{3} / \mathrm{MeOH}$ extract was devoid of activity. The activity of phytocompounds and their semisynthetic derivatives toward resistant bacteria was weak. The most active compound was $\beta$-sitosterol acetate, with a MIC value of $100 \mu \mathrm{g} / \mathrm{mL}$ against carbapenem-resistant $A$. baumannii. This is the first report of the secondary metabolites of $H$. glomerata Zucc. and the activity of its extracts and major pure compounds against resistant bacterial strains.
\end{abstract}

Keywords: infections; multi-drug resistant; phytochemistry; traditional medicine; northern America

\section{Introduction}

Infections by resistant bacteria represent a constant threat to human health and are becoming more difficult to treat each year [1]. In fact, the world is on the verge of a global crisis partially generated by 
the misuse of antibiotic agents and due to the unavailability of new drugs [2]. Drug resistant (DR), multi-drug resistant (MDR), and extremely drug resistant (XDR) bacterial infections are assumed to be responsible for thousands of human deaths every year and it is estimated that they will cause 10 million extra deaths worldwide by 2050 [3]. Thus, comprehensive efforts are necessary to reduce bacterial drug resistance, and to support the research and development of new effective drugs. The World Health Organization (WHO) published a list of bacterial strains with the greatest need of new antibiotics in 2017, prioritizing them based on the gravity of resistance as medium, high, or critical [4]. For these reasons, the discovery of new drugs is of utmost importance to control DR, MDR, and XDR bacterial infections.

Nature has always been a source of new and complex molecules and plant natural products have already proven useful in pharmaceutical chemistry [5]. The diversity of structures and biological activities of phytochemicals makes them very appealing from a new drug research and design point of view. Mexican medicinal plants are often used by the indigenous population to treat cancer and infections, among other diseases [6,7]. This knowledge makes them an interesting group of candidates for the research of new bioactive molecules that could be used directly or as lead compounds to treat bacterial infections.

In this work, we investigate the plant Hechtia glomerata Zucc., also known by the Mexican and Latino-American population as Guapilla or Lechuguilla. This plant is native to Guatemala, Mexico, and the southern regions of the United States, and is part of the family Bromeliaceae (56 genera and over 3000 species) [8]. Because of its vast distribution, it is considered today as the Bromeliad with the largest habitat [9]. In Mexico, there are 426 species of Bromeliaceae [10] and some are widely known, such as pineapple (Ananas comosus), and others have already been studied for pharmacological purposes [11-16] and part of their composition has already been elucidated [17,18]. H. glomerata is used both as a source of food and in ethnomedicine to treat various infections including bronchitis, laryngitis, nephritis, whooping cough, urethritis, and sepsis [19-22]. There are no chemical and pharmacological studies of $H$. glomerata. Therefore, a conventional phytochemical study of this plant was carried out. The extracts and pure isolated compounds were tested against resistant bacteria because it could be a source of antibacterial agents.

\section{Results and Discussion}

\subsection{Isolated and Derivatized Compounds from the Hexane and $\mathrm{CHCl}_{3} / \mathrm{MeOH}$ Extracts}

Five compounds were isolated and characterized from the Hex extract: nonacosane (1), hexatriacontanyl stearate (2), hexacosanol (3), oleic acid (4), and $\beta$-sitosterol (5). All are constituents of the vegetal cuticle. More specifically, compounds 1-4 are part of the waxes that cover the aerial part of plants [23], and perform a protective function, which prevents dehydration in arid environments [24]. A further five compounds were isolated and characterized from the $\mathrm{CHCl}_{3} / \mathrm{MeOH}$ extract: $p$-coumaric acid (6), margaric acid (7), caffeic acid (8), daucosterol (9), and potassium chloride (10). Compound 10 is an inorganic salt needed by halophyte plants to maintain homeostasis in their tissues [25]. Compound 9 is an abundant monoglycosylic saponin derivative of the aglycone 5, which is also in a high concentration in the Hex extract. Compounds 6 and 8 are abundant in cereals and grasses. These compounds have the most varied functions in plants and fungi and are precursors to different polyphenolic compounds. In particular, $p$-coumaric acid has a central role in the metabolism of these compounds and is the precursor of other phenolic compounds such as flavonoids, coumarins, lignans, lignin, and other secondary metabolites [26,27]. Some of the compounds $(4,5$, and 9$)$ were derivatized in order to improve their structural characterization and to investigate how their biological activity could change. Compounds 5 and 9 were acetylated, while compound 4 was methylated, giving the following derivatives: $\beta$-sitosteryl acetate (5a), daucosteryl tetraacetate $(9 a)$, and methyl oleate $(4 \mathrm{~m})$. 


\subsection{GC-MS Analysis of Hexane Extract and Two Solids Obtained from $\mathrm{CHCl}_{3} / \mathrm{MeOH}$ Extract}

A total of 49 compounds were identified from the Hex extract using Gas Chromatography Mass Spectrometry (GC-MS): 16 hydrocarbons (16.92\%), 15 fatty acids (FAs, 37.04\%), six steroids $(31.46 \%)$, four terpenoids $(4.65 \%)$, three long chain alcohols $(3.11 \%)$, three aldehydes $(0.35 \%)$, and two unknown compounds (6.47\%). The GC-MS analysis of two mixtures of lipophilic compounds (HG1 and HG2) isolated from the $\mathrm{CHCl}_{3} / \mathrm{MeOH}$ extract showed 17 volatile compounds. Ten of these compounds were also found in the Hex extract, while the others were only present in the HG1 and HG2 samples. A total of 58 volatile compounds were identified in the Hex extract and solids HG1 and HG2 (see Table 1).

Table 1. GC-MS analysis of Hex extract, compounds 1-5, HG1 and HG2 from H. glomerata.

\begin{tabular}{|c|c|c|c|}
\hline \multirow{2}{*}{ Compound } & \multirow{2}{*}{$\mathbf{R}_{\mathrm{T}}$ (Min) } & \multicolumn{2}{|c|}{$\%$ Area } \\
\hline & & Hex & HG1, HG2 \\
\hline Octanal & 10.580 & 0.09 & - \\
\hline Nonanal & 16.144 & 0.11 & - \\
\hline 1-Dodecene & 21.431 & - & 0.72 \\
\hline 2-(E)-Decenal & 25.918 & 0.15 & - \\
\hline 1-Tetradecene & 34.148 & - & 2.37 \\
\hline 1-Hexadecene & 45.946 & - & 1.37 \\
\hline Unknown & 50.143 & - & 0.02 \\
\hline 12-Methyltetradecanic acid (C14:0, anteiso) & 56.817 & 0.36 & - \\
\hline Pentadecanoic acid (C15:0) & 58.400 & 2.16 & - \\
\hline Isopropyl myristate & 58.419 & 0.03 & - \\
\hline Phytone & 59.332 & 2.65 & - \\
\hline$n$-Nonadecane & 62.006 & 0.16 & - \\
\hline Palmitoleic acid $(\mathrm{C} 16: 1, \Delta 9)$ & 62.183 & 0.68 & - \\
\hline Trachylobane & 65.054 & 0.11 & - \\
\hline Palmitic acid (C16:0) & 65.881 & 4.25 & - \\
\hline 5- $(E)$-Eicosene & 66.440 & 0.15 & - \\
\hline 14-Methylpalmitic acid (C17:0, iso) & 66.748 & 2.85 & - \\
\hline$n$-Eicosane & 66.755 & 0.29 & - \\
\hline 2-Hexyl-cyclopropaneoctanoic acid & 67.261 & 0.83 & - \\
\hline Kaur-16-ene & 67.497 & 0.16 & - \\
\hline Margaric acid (C18:0) & 68.036 & 0.75 & - \\
\hline Trans-vaccenic acid $(\mathrm{C} 18: 1, \Delta 11)$ & 69.632 & 0.53 & - \\
\hline$n$-Heneicosane & 71.366 & 3.04 & 7.34 \\
\hline Phytol & 71.918 & 1.72 & - \\
\hline Linoleic acid $(\mathrm{C} 18: 2, \Delta 9,12)$ & 73.842 & 8.35 & - \\
\hline Ethyl linoleate & 74.066 & 5.44 & - \\
\hline Ethyl oleate & 74.368 & 1.72 & - \\
\hline Nonadecenoic acid $(\mathrm{C} 19: 1, \Delta 13)$ & 74.374 & 1.64 & - \\
\hline Oleic acid $(\mathrm{C} 18: 1, \Delta 9)$ & 74.861 & 6.72 & - \\
\hline$n$-Docosane & 75.701 & 0.64 & 1.46 \\
\hline Gondonic acid $(\mathrm{C} 20: 1, \Delta 11)$ & 79.872 & 0.74 & - \\
\hline$n$-Tricosane & 80.162 & - & 6.16 \\
\hline Cyclotetracosane & 83.689 & 0.14 & - \\
\hline n-Tetracosane & 84.004 & 0.55 & 1.12 \\
\hline 12-(Z)-Pentacosene & 87.591 & 0.07 & - \\
\hline n-Pentacosane & 88.005 & 2.40 & 3.82 \\
\hline Unknown & 89.528 & 3.23 & 1.24 \\
\hline 9-Hexacosene & 91.381 & 0.63 & 2.27 \\
\hline n-Hexacosane & 91.676 & 0.64 & 1.28 \\
\hline 12-(Z)-heptacosene & 95.033 & 0.50 & - \\
\hline n-Heptacosane & 95.243 & 1.05 & 6.63 \\
\hline Unknown & 96.747 & 3.24 & - \\
\hline Cycloocatacosane & 98.909 & - & 12.78 \\
\hline n-Octacosane & 99.040 & - & 3.00 \\
\hline
\end{tabular}


Table 1. Cont.

\begin{tabular}{cccc}
\hline Compound & \multirow{2}{*}{$\mathbf{R}_{\mathbf{T}}(\mathbf{M i n})$} & \multicolumn{2}{c}{ \% Area } \\
\cline { 3 - 4 } & & Hex & HG1, HG2 \\
\hline Nonacosanol & 101.871 & 0.19 & - \\
$n$-Nonacosane & 102.219 & 4.19 & 28.63 \\
1-Triacontanol & 105.313 & - & 1.70 \\
$n$-Triacontane & 105.497 & 0.33 & 2.56 \\
Hentriacontane & 108.545 & 2.13 & 8.18 \\
Ergosterol & 110.896 & 0.24 & - \\
Campesterol & 111.573 & 5.38 & - \\
Stigmasterol & 112.512 & 1.37 & - \\
Hentriacontanol & 112.867 & 0.14 & - \\
1,30-Triacontanediol & 113.175 & 2.78 & - \\
$\beta$-Sitosterol & 114.607 & 17.97 & - \\
Dotriacontenol & 114.969 & - & 7.34 \\
(3ß,5 $\alpha$ )-Ergostanol & 115.921 & 0.49 & - \\
Stigmast-4-en-3-one & 118.233 & 6.02 & - \\
\hline
\end{tabular}

$\mathrm{R}_{\mathrm{T}}$ : Retention time. The compounds were identified using the National Institute of Standards and Technology (NIST) mass spectral database (version 1.7a).

If we compare the constituents of Hex extract and the solids HG1 and HG2, we can see quantitative and qualitative differences. The Hex extract was mainly composed of fatty acids (FAs) and their derivatives including: eleven FAs, three FA esters, three fatty alcohols, and three aldehydes. The FAs were made up of a higher quantity of unsaturated fatty acids (UFAs, $18.66 \%$ ) than saturated fatty acids (SAFAs, $11.20 \%$ ).

Fatty alcohols are derivatives of the reduction of FAs and are involved in plant biosynthesis of esters and waxes [23]. The three aldehydes known as octanal $(0.09 \%)$, nonanal $(0.11 \%)$, and 2-(E)-decenal $(0.15 \%)$ can be obtained from oxidation of fatty alcohols or reduction of FAs [28]. The second most abundant group of compounds was the hydrocarbons group including alkanes (15.56\%) and alkenes $(1.36 \%)$. The alkanes can be derived by decarboxylation of long chain FAs [29]. As mentioned before, hydrocarbons and fatty acids are the main constituents of plant cuticles, which explain why they are so abundant in the extract.

The rest of the compounds were terpenoids and steroids. Among the terpenoids were phytol $(1.72 \%)$ and its derivative phytone $(2.65 \%)$. Other terpenoid compounds identified were trachylobane $(0.11 \%)$ and kaur-16-ene $(0.16 \%)$. These trachylobane and kaurane diterpenoids are considered to be intermediates in the biosynthesis of the plant growth hormones gibberellins [30]. Terpenoids and steroids are also part of the cuticle. Among the sterols were $\beta$-sitosterol (17.97\%), campesterol (5.38\%), and stigmasterol (1.37\%), which are very common in plants [31]. Lastly, the volatile compounds identified in the solids HG1 and HG2 were 12 alkanes (82.96\%), four alkenes (6.73\%), and two fatty alcohols $(9.04 \%)$.

\subsection{UPLC-QTOF-MS Analysis of the Aqueous Extract}

Fifty-five compounds were identified from the ultra-high performance liquid chromatography quadrupole time-of-flight mass spectrometry (UPLC-QTOF-MS) analysis of the aqueous extract (Table 2). These compounds included 30 flavonoids (55.21\%), nine phenolic compounds (15.80\%), five saponins $(9.43 \%)$, three terpenoids $(5.46 \%)$, two stilbenes (3.97\%), one nitrogen-containing compound (N-compounds, $2.10 \%$ ), and five unknown compounds (8.03\%). The major identified compounds were flavonoids derivatized with one or more sugar moieties. Some of these compounds were anthocyanins and anthocyanidins (21.06\%), which are plant pigments already reported in the Bromeliaceae family [32]. One of the identified compounds was ananaflavoside B, previously identified in Ananas comosus [33]. 
Table 2. Components identified from the aqueous extract of $H$. glomerata by UPLC-QTOF-MS.

\begin{tabular}{|c|c|c|c|c|c|}
\hline Compound & $\underset{(\min )}{\mathbf{R}_{\mathrm{T}}}$ & $\begin{array}{l}\text { Molecular } \\
\text { Formula }\end{array}$ & $\begin{array}{c}\text { Experimental } \\
m / z\end{array}$ & $\begin{array}{l}\text { Error } \\
(\mathrm{ppm})\end{array}$ & $\begin{array}{c}\text { Means of } \\
\text { Identification }\end{array}$ \\
\hline 3,8-Diglucosyldiosmetin & 1.967 & $\mathrm{C}_{28} \mathrm{H}_{32} \mathrm{O}_{16}$ & 625.167 & 0.93 & Foodb \\
\hline 5,7-Dihydroxy-6-methoxyisoflavone 7-O-rhamnoside & 2.986 & $\mathrm{C}_{22} \mathrm{H}_{22} \mathrm{O}_{9}$ & 431.1264 & 0.73 & Foodb \\
\hline Unknown & 3.962 & - & 412.259 & - & - \\
\hline Delphinidin 3-sophoroside 5-glucoside & 4.771 & $\mathrm{C}_{33} \mathrm{H}_{41} \mathrm{O}_{22}{ }^{+}$ & 789.67 & -4.61 & Foodb \\
\hline Phytyl monophosphate & 5.023 & $\mathrm{C}_{20} \mathrm{H}_{39} \mathrm{O}_{4} \mathrm{P}$ & 375.1947 & 7.23 & Foodb \\
\hline Catechin $4^{\prime}$-methyl ether & 5.543 & $\mathrm{C}_{16} \mathrm{H}_{16} \mathrm{O}_{6}$ & 305.095 & 0.73 & Foodb \\
\hline 6-tuliposide A & 5.945 & $\mathrm{C}_{11} \mathrm{H}_{18} \mathrm{O}_{8}$ & 279.1519 & -4.45 & Foodb \\
\hline Daucosterol & 6.152 & $\mathrm{C}_{35} \mathrm{H}_{60} \mathrm{O}_{6}$ & 577.86 & -4.24 & [33] \\
\hline Peonidin & 6.346 & $\mathrm{C}_{18} \mathrm{H}_{20} \mathrm{O}_{4}^{+}$ & 301.1339 & -6.27 & Foodb \\
\hline Unknown & 6.356 & - & 325.130 & - & - \\
\hline Guanosine pentaphosphate & 6.377 & $\mathrm{C}_{10} \mathrm{H}_{12} \mathrm{~N}_{5} \mathrm{O}_{17} \mathrm{P}_{4}$ & 599.123 & 1.63 & PMN \\
\hline Epicatechin 3-O-gallate & 6.421 & $\mathrm{C}_{22} \mathrm{H}_{18} \mathrm{O}_{10}$ & 443.3262 & -2.29 & Foodb \\
\hline Chlorogenoquinone & 6.442 & $\mathrm{C}_{18} \mathrm{H}_{24} \mathrm{O}_{7}$ & 353.1502 & -6.35 & Foodb \\
\hline Tetramethylquercetin & 6.474 & $\mathrm{C}_{19} \mathrm{H}_{18} \mathrm{O}_{7}$ & 359.3165 & -2.03 & Foodb \\
\hline Kaempferol 3-O-rutinoside & 6.573 & $\mathrm{C}_{27} \mathrm{H}_{30} \mathrm{O}_{15}$ & 594.159 & 1.01 & [33] \\
\hline Luteolin 7-(2"-apiosylglucoside) & 6.643 & $\mathrm{C}_{26} \mathrm{H}_{28} \mathrm{O}_{15}$ & 581.143 & 0.73 & [33] \\
\hline Ergosterol endoperoxide & 6.714 & $\mathrm{C}_{28} \mathrm{H}_{44} \mathrm{O}_{3}$ & 429.311 & 2.53 & {$[33]$} \\
\hline 1,28-Dicaffeoyloctacosanediol & 6.761 & $\mathrm{C}_{46} \mathrm{H}_{70} \mathrm{O}_{8}$ & 751.5143 & -0.01 & Foodb \\
\hline 1,26-Hexacosanediol diferulate & 6.761 & $\mathrm{C}_{46} \mathrm{H}_{70} \mathrm{O}_{8}$ & 751.507 & 0.73 & Foodb \\
\hline Proanthocyanin monogallate & 6.761 & $\mathrm{C}_{36} \mathrm{H}_{56} \mathrm{O}_{15}$ & 729.829 & -6.79 & Respect \\
\hline Epicatechin 3-O-(3-O-methylgallate) & 7.160 & $\mathrm{C}_{23} \mathrm{H}_{20} \mathrm{O}_{10}$ & 457.2491 & -1.36 & Foodb \\
\hline Piceid & 7.26 & $\mathrm{C}_{20} \mathrm{H}_{22} \mathrm{O}_{8}$ & 391.2785 & -1.40 & PhytoHub \\
\hline Cyanidin-3-O-( $2^{\prime \prime}-O-\beta$-xylopyranosyl- $\beta$-glucopyranoside $)-5-O-\beta$-glucopyranoside & 7.274 & $\mathrm{C}_{32} \mathrm{H}_{39} \mathrm{O}_{20}{ }^{+}$ & 745.625 & 1.50 & Respect \\
\hline Tricin 10 & 7.300 & $\mathrm{C}_{17} \mathrm{H}_{14} \mathrm{O}_{7}$ & 331.1676 & -8.64 & Foodb \\
\hline Kaempferol 3-triglucoside-7-rhamnoside-p-coumaroyl & 7.345 & $\mathrm{C}_{48} \mathrm{H}_{56} \mathrm{O}_{27}$ & 1065.309 & -0.90 & Respect \\
\hline Spinacetin 3-O-glucosyl-(1->6)-[apiosyl(1->2)]-glucoside & 7.348 & $\mathrm{C}_{34} \mathrm{H}_{42} \mathrm{O}_{22}$ & 803.684 & -4.60 & PhytoHub \\
\hline Hexosyl-hexosyl-soyasapogenol E & 7.348 & $\mathrm{C}_{42} \mathrm{H}_{68} \mathrm{O}_{13}$ & 780.47 & - & Phytohub \\
\hline Oleanolic acid 3-O-glucose $\left(1^{\prime \prime}->3^{\prime}\right)$ arabinose & 7.348 & $\mathrm{C}_{41} \mathrm{H}_{66} \mathrm{O}_{12}$ & 751.460 & 0.27 & Foodb \\
\hline 3-O-Rutinosyl-3'-O-glucopyranosyl cyanidin & 7.382 & $\mathrm{C}_{33} \mathrm{H}_{41} \mathrm{O}_{20}{ }^{+}$ & 757.67 & -4.51 & [33] \\
\hline Quercetin-3-Galactoside- $6^{\prime \prime}$-Rhamnoside-3'" -Rhamnoside & 7.386 & $\mathrm{C}_{34} \mathrm{H}_{42} \mathrm{O}_{20}$ & 771.700 & -0.47 & Respect \\
\hline $3,7,3^{\prime}$-O-Triglucopyranosyl-dephinidine & 7.386 & $\mathrm{C}_{33} \mathrm{H}_{41} \mathrm{O}_{22}{ }^{+}$ & 789.570 & 1.00 & [33] \\
\hline Hederagenin 3-O-hexose-pentose & 7.391 & $\mathrm{C}_{41} \mathrm{H}_{66} \mathrm{O}_{13}$ & 766.430 & 2.00 & Respect \\
\hline Prenyl caffeate & 7.413 & $\mathrm{C}_{14} \mathrm{H}_{16} \mathrm{O}_{4}$ & 249.121 & 0.24 & $\begin{array}{c}\text { Foodb, } \\
\text { PhytoHub }\end{array}$ \\
\hline Peonidin 3-sophoroside & 7.555 & $\mathrm{C}_{28} \mathrm{H}_{33} \mathrm{O}_{16}^{+}$ & 625.177 & 0.01 & $\begin{array}{l}\text { PhytoHub } \\
\text { Foodb }\end{array}$ \\
\hline Unknown & 7.776 & $-28+16$ & 348.486 & - & - \\
\hline Trihydroxycinnamoylquinic acid & 7.801 & $\mathrm{C}_{16} \mathrm{H}_{18} \mathrm{O}_{10}$ & 371.200 & -1.10 & Respect \\
\hline Cinnamtannin B1 & 7.802 & $\mathrm{C}_{45} \mathrm{H}_{36} \mathrm{O}_{18}$ & 865.6147 & -4.17 & Phytohub \\
\hline Galloylquinic acid isomer & 7.827 & $\mathrm{C}_{38} \mathrm{H}_{40} \mathrm{O}_{19}$ & 801.220 & -1.06 & Foodb \\
\hline Agavoside B & 7.837 & $\mathrm{C}_{34} \mathrm{H}_{42} \mathrm{O}_{19}$ & 755.686 & -2.65 & Foodb \\
\hline Cyanidin 3,5,3'-tri-O-glycoside & 7.838 & $\mathrm{C}_{33} \mathrm{H}_{41} \mathrm{O}_{21}{ }^{+}$ & 774.595 & -3.74 & [33] \\
\hline Unknown & 7.874 & - & 674.579 & - & - \\
\hline Luteolin 7-O-(2-apiosyl-6-malonyl)-glucoside & 7.876 & $\mathrm{C}_{29} \mathrm{H}_{30} \mathrm{O}_{18}$ & 667.538 & -3.87 & Foodb \\
\hline Petunidin 3-O-(6-O-acetyl)-glucoside & 7.901 & $\mathrm{C}_{24} \mathrm{H}_{25} \mathrm{O}_{13}{ }^{+}$ & 522.589 & -4.53 & Foodb \\
\hline Piceatannol $4^{\prime}$-glucoside & 8.022 & $\mathrm{C}_{20} \mathrm{H}_{22} \mathrm{O}_{9}$ & 407.129 & 0.51 & Foodb \\
\hline Peonidin 3-rhamnoside & 8.185 & $\mathrm{C}_{22} \mathrm{H}_{23} \mathrm{O}_{10}{ }^{+}$ & 447.361 & -2.32 & Foodb \\
\hline Myricetin $3,3^{\prime}$-digalactoside & 8.228 & $\mathrm{C}_{27} \mathrm{H}_{30} \mathrm{O}_{18}$ & 643.519 & -3.69 & [33] \\
\hline Aloesol 7-glucoside & 8.248 & $\mathrm{C}_{19} \mathrm{H}_{24} \mathrm{O}_{9}$ & 397.1759 & -2.62 & Foodb \\
\hline Delphinidin 3-rutinoside 5-glucoside & 8.299 & $\mathrm{C}_{33} \mathrm{H}_{41} \mathrm{O}_{21}{ }^{+}$ & 774.669 & -4.48 & Foodb \\
\hline Myricitrin glucoside & 8.302 & $\mathrm{C}_{21} \mathrm{H}_{20} \mathrm{O}_{12}$ & 465.0954 & 0.74 & [33] \\
\hline Luteolin 7-O-diglucuronide & 8.341 & $\mathrm{C}_{27} \mathrm{H}_{26} \mathrm{O}_{18}$ & 639.485 & -3.65 & foodb \\
\hline Unknown & 8.856 & - & 426.729 & - & - \\
\hline 3-O-Glucopyranosyl-6,3',5'-trimethoxy-3,5,7,4'-tetrahydroxyflavone & 9.401 & $\mathrm{C}_{24} \mathrm{H}_{26} \mathrm{O}_{14}$ & 539.460 & 1.10 & [33] \\
\hline Zeaxanthin & 9.401 & $\mathrm{C}_{40} \mathrm{H}_{56} \mathrm{O}_{2}$ & 569.881 & -4.46 & PMN \\
\hline Ananaflavoside B & 10.158 & $\mathrm{C}_{25} \mathrm{H}_{28} \mathrm{O}_{13}$ & 537.3871 & 1.03 & [33] \\
\hline Isochlorogenic acid B & 10.158 & $\mathrm{C}_{26} \mathrm{H}_{26} \mathrm{O}_{11}$ & 515.483 & -3.35 & PhytoHub \\
\hline
\end{tabular}

Phenolic compounds were also identified from the aqueous extract including isochlorogenic acid $(2.06 \%)$ and aloesol 7 -glucoside $(1.62 \%)$. Aloesol is a chromone, which is produced by the same pathway as flavonoids and coumarins. Aloesol has never been reported in the Bromeliaceae family, but was previously reported as a constituent of Aloe vera (Liliaceae) [34]. Chromones, much like flavonoids, have antioxidant activity and provide a defense against pests. Furthermore, chromones also have antifungal activity [35]. Other compounds identified include the steroidal saponins: daucosterol $(2.12 \%)$ and agavoside B $(1.44 \%)$, stilbenes: piceid $(2.45 \%)$ and piceatannol $(1.51 \%)$, terpenoids: ergosterol endoperoxide $(1.97 \%)$, and zeaxanthin $(1.47 \%)$, and the N-compound, guanosine pentaphosphate.

\subsection{Antibacterial Activity}

Extracts and major pure compounds were evaluated for their activity against resistant bacteria. Table 3 shows that the Hex extract and the aqueous extract has antibacterial activity against E. coli extended spectrum $\beta$-lactamase (ESBL), and three strains of K. pneumoniae: oxacillin, ESBL, and New Delhi metallo- $\beta$-lactamase 1 (NDM-1), with a minimum inhibitory concentration (MIC) value of $500 \mu \mathrm{g} / \mathrm{mL}$. The $\mathrm{CHCl}_{3} / \mathrm{MeOH}$ extract showed null activity against all resistant strains tested. It is possible that 
the activity of the $\mathrm{CHCl}_{3} / \mathrm{MeOH}$ extract against resistant bacteria was masked or inhibited by other compounds present in this extract.

Table 3. Activity of H. glomerata leaves extracts, major isolated compounds, and their semisynthetic derivatives against resistant bacteria.

\begin{tabular}{|c|c|c|c|c|c|c|c|c|c|}
\hline \multirow[b]{2}{*}{ Extracts } & \multicolumn{9}{|c|}{$\operatorname{MIC}(\mu \mathrm{g} / \mathrm{mL})$} \\
\hline & $\begin{array}{l}\text { S. aureus } \\
\text { methicillin }\end{array}$ & $\begin{array}{l}\text { S. epidermidis } \\
\text { Linezolid }\end{array}$ & $\begin{array}{c}\text { E. faecium } \\
\text { Vancomycin }\end{array}$ & $\begin{array}{l}\text { A. baumannii } \\
\text { Carbapenems }\end{array}$ & $\begin{array}{l}\text { P. aeruginosa } \\
\text { Carbapenems }\end{array}$ & $\begin{array}{l}\text { E. coli } \\
\text { ESLB }\end{array}$ & $\begin{array}{l}\text { K. Pneumoniae } \\
\text { NDM-1 + }\end{array}$ & $\begin{array}{l}\text { K. pneumoniae } \\
\text { ESBL }\end{array}$ & $\begin{array}{l}\text { K. Pneumoniae } \\
\text { Oxacillin }\end{array}$ \\
\hline Hex & $>500$ & $>500$ & $>500$ & $>500$ & $>500$ & 500 & 500 & 500 & 500 \\
\hline \multirow[t]{2}{*}{ Aqueous } & $>500$ & $>500$ & $>500$ & $>500$ & $>500$ & 500 & 500 & 500 & 500 \\
\hline & \multicolumn{9}{|c|}{ Compounds } \\
\hline 5 & $>200$ & 200 & 200 & 200 & 200 & $>200$ & 200 & $>200$ & $>200$ \\
\hline 9 & $>200$ & 200 & 200 & 200 & 200 & $>200$ & $>200$ & $>200$ & $>200$ \\
\hline $9 a$ & $>200$ & $>200$ & 200 & 200 & 200 & $>200$ & $>200$ & $>200$ & $>200$ \\
\hline Levofloxacin & 12.5 & 6.25 & 12.5 & 12.5 & 0.78 & 25 & $>50$ & 0.78 & 12.5 \\
\hline
\end{tabular}

The antibacterial properties of the Hex extract may be linked with the good quantity of FAs contain in it, especially unsaturated fatty acids (UFAs) such as linoleic acid. Some FAs have been reported to have antibacterial activities against different strains of bacteria and mycobacteria. The mechanism of action involved in their antibacterial activity has been shown to involve the inhibition of the bacterial enzyme enoyl-acyl carrier protein reductase (FabI) [36]. It has been reported that phytol has activity against eight bacterial and eight fungal strains, which show a strong antibacterial effect with MICs between 3 and $38 \mu \mathrm{g} / \mathrm{mL}$ against Bacillus cereus, Micrococcus luteus, Listeria monocytogenes, P. aeruginosa, Salmonella typhimurium, E. coli, Enterobacter cloacae, and Micrococcus flavus [37]. In other studies, sub-lethal concentrations $(0.5,0.25$, and $0.125 \mathrm{MIC})$ of phytol have shown anti-quorum sensing on $P$. aeruginosa [38]. Pythone is also believed to be an antibacterial agent, which has been reported as part of some plant essential oils that displayed antibacterial activity against sensitive bacteria [39]. The diterpenoids trachylobane and kaur-16-ene are also reported to have antibacterial activity [40].

Regarding stigmasterol and campesterol, few reports have tested these sterols as pure compounds, but the biological activity of their mixtures and derivatives is well reported. For example, their acetylated derivatives have shown antibacterial activity against $S$. aureus, E. coli, P. aeruginosa, and Klebsiella [41]. $\beta$-Sitosterol and daucosterol, which are in high concentration in the organic extracts of H. glomerata, are reported to have no antibacterial properties against E. coli, S. aureus, and K. pneumonie $(\mathrm{MIC}>500 \mu \mathrm{g} / \mathrm{mL})$ [42].

The activity of the aqueous extract is also partially explained by its composition. The high content of flavonoids is likely the main reason for the antibacterial activity of this extract [43]. Luteolin and kaempferol were found as glycoside derivatives in the extract. Kaempferol has been reported as active against methicillin-resistant $S$. aureus (MRSA), vancomycin-resistant enterococci (VRE), and Burkholderia cepacia, with MICs of $512 \mu \mathrm{g} / \mathrm{mL}$. Luteolin was active against E. coli, K. pneumoniae, and P. aeruginosa (ATCC) presenting MICs of $125 \mu \mathrm{g} / \mathrm{mL}$ for all strains [44]. Other molecules with antimicrobial activity include chromones such as aloesol and its derivatives, which are being studied as mushroom tyrosinase inhibitors [35]. The saponins identified in the aqueous extract might also account as part of its activity against the resistant bacteria. For example, hederagenin was tested against three strains of S. aureus (ATCC 6538p, 25923, 29213) and various Gram-negative strains comprising P. aeruginosa (ATCC 27853), A. baumannii (ATCC 19606), and E. coli (ATCC 25922, 8739). This saponin was active (MIC 400-500 $\mu \mathrm{g} / \mathrm{mL}$ ) against the Gram-positive bacteria, whereas the Gram-negative strains were unaffected at any concentration [45]. Triterpene saponins of oleanolic acid have also been shown to have antibacterial activity against S. aureus, P. aeruginosa, and K. pneumoniae, with MICs ranging from 3.125 to $6.25 \mu \mathrm{g} / \mathrm{mL}$ [46]. Stilbenes have been reported to inhibit the electron transport chain (ETC), the cleavage of deoxyribonucleic acid (DNA), and cell division, and also shown to have antibiofilm activity [47]. 
The stilbene piceid is the main glycosylated derivative of resveratrol, and had activity against foodborne pathogens including $S$. aureus and E. coli with a MIC value ranging from 0.625 to $521 \mu \mathrm{g} / \mathrm{mL}$ against the Gram-positive bacteria, and, for Gram-negative bacteria, ranging from 16.5 to $260 \mu \mathrm{g} / \mathrm{mL}$ [48]. In another study, resveratrol was tested against S. aureus (ATCC 25923), methicillin-sensitive S. aureus (MSSA), MRSA, E. coli (ATCC 25922), E. coli (clinical isolate), K. pneumoniae (ATCC 13883), K. pneumoniae (clinical isolate), P. aeruginosa (ATCC 27853), and P. aeruginosa (clinical isolate). For the Gram-positive bacteria, the MIC value range was from 50 to $200 \mu \mathrm{g} / \mathrm{mL}$, while, for the Gram-negative bacteria, MICs were higher than $400 \mu \mathrm{g} / \mathrm{mL}$ [49]. Piceatannol was reported to have inhibitory activity against some bacterial strains obtained from the National Collection of Type Culture (NCTC) like S. aureus (NCTC 6571) and E. coli (NCTC 10418) with MICs of 25 and $50 \mu \mathrm{g} / \mathrm{mL}$ respectively, while no effect was reported for $P$. aeruginosa (>1000 $\mu \mathrm{g} / \mathrm{mL})$ [50].

In our study, two of the most abundant isolated compounds and their derivatives were tested for antibacterial activity (Table 3). $\beta$-Sitosterol showed weak activity (MIC $200 \mu \mathrm{g} / \mathrm{mL}$ ) against linezolid-resistant S. epidermidis, vancomycin-resistant E. faecium, carbapenem-resistant $A$. baumannii, carbapenem-resistant P. aeruginosa, and NDM-1 K. pneumoniae. $\beta$-Sitosterol acetate displayed weak activity (MIC $200 \mu \mathrm{g} / \mathrm{mL}$ ) toward linezolid-resistant $S$. epidermidis, vancomycin-resistant E. faecium, carbapenem-resistant P. aeruginosa, ESBL E. coli, and ESBL K. pneumoniae, and moderate activity against carbapenem-resistant A. baumannii (MIC $100 \mu \mathrm{g} / \mathrm{mL}$ ). Daucosterol showed weak activity (MIC $200 \mu \mathrm{g} / \mathrm{mL}$ ) against linezolid-resistant S. epidermidis, vancomycin-resistant $E$. faecium, carbapenem-resistant $A$. baumannii, and carbapenem-resistant P. aeruginosa. Daucosteryl tetracetate had weak activity (MIC $200 \mu \mathrm{g} / \mathrm{mL}$ ) toward vancomycin-resistant E. faecium, carbapenem-resistant $A$. baumanii, and carbapenem-resistant $P$. aeruginosa. The activity of the phytocompounds and their semisynthetic derivatives toward resistant bacteria was weak. The most active compound was $\beta$-sitosteryl acetate, with a MIC of $100 \mu \mathrm{g} / \mathrm{mL}$ against carbapenem-resistant A. baumannii. It has been reported that this compound had some activity on the growth of various bacterial strains, such as S. aureus, E. coli, and K. pneumoniae [51]. Daucosterol and its tetraacetate derivative gave almost the same results of antibacterial activity. These molecules are larger than their aglycones. Thus, they are not able to reach the cytoplasm and exert their effect on bacteria. In our study, $p$-coumaric acid did not have any activity at the highest concentration, whereas caffeic acid inhibited the growth of two Gram-positive resistant bacterial strains S. epidermidis and E. faecium (MICs: $200 \mu \mathrm{g} / \mathrm{mL}$ ). Reports in the literature about the antibacterial activity of $p$-coumaric acid are contradictory. Lou et al. found that this compound inhibited Gram-positive bacteria such as S. aureus (MIC: $20 \mu \mathrm{g} / \mathrm{mL}$ ) and Gram-negative bacteria E. coli (MIC: $80 \mu \mathrm{g} / \mathrm{mL}$ ). It was also reported that $p$-coumaric acid has a double damage mechanism of action comprising an increase in membrane permeability and binding on the phosphate anion of bacterial DNA [52]. In other works, the activity of this compound against $S$. aureus has been reported as much higher (MIC: $625 \mu \mathrm{g} / \mathrm{mL}$ ) or completely absent for both $p$-coumaric acid and caffeic acid (MIC $>1 \mathrm{mg} / \mathrm{mL}$ ) against $S$. aureus, S. epidermidis, and E. coli [53]. Therefore, the inactivity of $p$-coumaric acid and caffeic acid against the tested Gram-negative strains and the inactivity of $p$-coumaric acid against the Gram-positive strains might be a result of the drug resistance of the tested bacteria.

From the above results, the activity of H. glomerata against resistant bacteria can be partly explained. However, it will be necessary to test the above extracts against sensitive bacteria strains and carry out a bio-assay guided study on the active extracts to isolate their active compounds in order to explain the use of this plant in Mexican traditional medicine. Furthermore, preparing other semisynthetic analogues of the most active compound should be considered to do a structure-activity relationship (SAR) study and improve its antibacterial activity.

\section{Materials and Methods}

\subsection{General}

The chemicals and reagents were acquired commercially from Sigma-Aldrich and Baker. Melting points (mp) were measured with a Thermo Scientific P12144Q Fisher-Johns Melting Point 
Apparatus (Thermo Fisher Scientific, Waltham, MA, USA). IR spectra were recorded with a Bruker ALPHA ATR-FTIR spectrometer (Bruker, Billerica, MA, USA). The 1D and 2D NMR spectra were obtained on a Bruker NMR Avance IIIHD spectrometer (Bruker Biospin, Billerica, MA, USA) operating at 400 and $100 \mathrm{MHz}$, respectively, for ${ }^{1} \mathrm{H}$ and ${ }^{13} \mathrm{C}$ measurements. For the ${ }^{13} \mathrm{C}$ NMR spectra, multiplicities were determined by DEPT experiments $\left(90^{\circ}\right.$ and $\left.135^{\circ}\right)$. X-ray diffraction (XRD) data were obtained in a Bruker SMART APEX and a Bruker-D2 Phaser (Bruker, Billerica, MA, USA). Normal phase TLCs were on Silica gel 60 F254 precoated on aluminum and glass (Merck \& Co., Kenilworth, NJ, USA) and were visualized under UV light $\left(254\right.$ and $365 \mathrm{~nm}$ ) and with a $\mathrm{Ce}\left(\mathrm{SO}_{4}\right)_{2} / \mathrm{H}_{2} \mathrm{SO}_{4}$ solution. Reverse phase TLCs were on C18 substrate precoated on glass and were visualized under UV light (254 and $365 \mathrm{~nm})$ and with a $\mathrm{Ce}\left(\mathrm{SO}_{4}\right)_{2} / \mathrm{H}_{2} \mathrm{SO}_{4}$ solution. Column chromatography was carried out on silica gel 230-400 mesh (EMD Chemicals Inc., Port Wentworth, GA, USA) and eluted with gradients of solvents. GC-MS data were obtained using an Agilent 6890 instrument with EI (70 eV) and Mass Selective Detector Agilent 5973N (Agilent, Santa Clara, CA, USA). The molecules were identified using the NIST mass spectral library version 1.7a. UPLC-MS data were obtained with an Agilent Technologies series 1290 infinity II instrument with the ESI ion source and QTOF Agilent Technologies G6545 model detector (Agilent, 5301 Stevens Creek Blvd, Santa Clara, CA 95051, USA). The tentative identification of the components was realized using open access web databases: FooDB, ReSpect for Phytochemicals (ReSpect), PhytoHub, and Plant Metabolic Network (PMN) and by comparison with the reported data in the literature. For the antibacterial assays, microplates were read with a Bio-Rad LightOne Illuminator (Bio-Rad Laboratories, Hercules, CA, USA).

\subsection{Plant Material}

The vegetal material was collected in Rayones ( $25^{\circ} 01^{\prime} 00^{\prime \prime} \mathrm{N} 100^{\circ} 05^{\prime} 00^{\prime \prime} \mathrm{W}, 906 \mathrm{~m}$ a.s.l.), Nuevo León, Mexico. The plant was collected and identified by the biologist Mauricio González Ferrara on 15 February 2017. A voucher reference (028029) was deposited at the herbarium of the Faculty of Biology, Universidad Autónoma de Nuevo León. The plant name has been checked in the website http://www.theplantlist.org/.

\subsection{Extracts Preparation}

Plant leaves $(10.5 \mathrm{~kg})$ were cleaned of residual dirt and cleaved from the pinecones, which were discarded. Then the leaves were cut into 2 to $3 \mathrm{~cm}$ long pieces. Part of the cut leaves $(300 \mathrm{~g})$ was ground fresh with distilled water $(850 \mathrm{~mL})$ to obtain a fresh aqueous extract. The majority of the cut leaves were then left to dry in the dark. Once dried, the vegetal material $(2.29 \mathrm{~kg})$ was ground first with a coffee grinder and then with a blender. Dried and ground material was macerated sequentially first with hexane (Hex) $(10 \mathrm{~L} \times 1,24 \mathrm{~h})$, and then with a chloroform $\left(\mathrm{CHCl}_{3}\right) /$ methanol $(\mathrm{MeOH})$ 1:1 mixture $(10 \mathrm{~L} \times 6,24 \mathrm{~h})$. The organic extracts were dried in vacuo whereas the aqueous extract was lyophilized. The above procedure resulted in the production of $\mathrm{Hex}(9.5 \mathrm{~g} ; 0.48 \%), \mathrm{CHCl}_{3} / \mathrm{MeOH}(87 \mathrm{~g}$; $4.38 \%)$, and aqueous extract $(8.3799 \mathrm{~g}, 2.79 \%)$, which were kept at $-20^{\circ} \mathrm{C}$ until use.

\subsection{Fractionation, Isolation, Purification, and Characterization of Compounds}

The Hex extract ( $9.0 \mathrm{~g}$ ) was passed through a column chromatography (CC) on silica gel (180 g) and eluted with a gradient of Hex/EtOAc, obtaining a total of 226 fractions of $50 \mathrm{~mL}$ each. These fractions were analyzed by thin layer chromatography (TLC) under ultraviolet (UV) light, stained with $\mathrm{Ce}\left(\mathrm{SO}_{4}\right)_{2}$, and pooled according to their similarity into 16 fractions named from A to P. From fraction A ( $203.1 \mathrm{mg}$, $100 \%$ hex), a white solid (178.2 mg, 0.009\%) precipitated, which was washed in cold Hex. This solid (mp 43-46 ${ }^{\circ} \mathrm{C}$ ) was soluble in chloroform, and its nuclear magnetic resonance (NMR) spectra showed typical signals of the alkane nonacosane (1) [54]. From fractions C to F (Hex/EtOAc 98:2-92:8), a white solid $(266.8 \mathrm{mg}, 0.0143 \%)$ precipitated, which was washed in cold Hex. This solid ( $\mathrm{mp} 73-75^{\circ} \mathrm{C}$ ) was soluble in $\mathrm{CHCl}_{3}$, and it was identified as hexatriacontanyl stearate (2) [55]. From fraction $\mathrm{G}$ (1.4490 g, Hex/EtOAc 90:10), a white solid (118 mg, 0.0015\%) precipitated, which was passed through a CC on 
silica gel (2.36 g) eluted with a gradient of Hex/dichloromethane (DCM) yielding a white crystalline solid $(29.3 \mathrm{mg}, 0.0015 \%)$ soluble in pyridine with an $\mathrm{mp} 76-77^{\circ} \mathrm{C}$ and characterized as hexacosanol (3) [56]. Fraction $\mathrm{G}$ was passed through four consecutive CCs on silica gel and eluted with different gradients of solvents (Hex/EtOAc x2, $\mathrm{CHCl}_{3} / \mathrm{EtOAc} \times 2$ ). The last CC yielded 90 subfractions (sf), the sf 57-62 (161 mg) was then treated with a preparative TLC eluted with Hex/acetone/acetic acid (85:7.5:7.5). This procedure yielded a colorless oil $(17.7 \mathrm{mg}, 0.0009 \%)$ characterized as oleic acid (4) [57]. Fraction $\mathrm{H}$ (366.5 mg, Hex/EtOAc 90:10-85:15) was treated with a CC on silica gel (11 g) eluted with a gradient of Hex/EtOAc, which yielded 57 sf. Sf 4-5 (Hex/EtOAc 85:15) and yielded a white solid (273.1 mg, $0.0138 \%$ ) soluble in $\mathrm{CHCl}_{3}, \mathrm{mp} 138-140{ }^{\circ} \mathrm{C}$. It was characterized as $\beta$-sitosterol (5) [58].

The $\mathrm{CHCl}_{3} / \mathrm{MeOH}$ extract $(85 \mathrm{~g})$ was processed by $\mathrm{CC}$ on silica gel $(2 \mathrm{~kg})$ and eluted with a gradient of $\mathrm{Hex} / \mathrm{EtOAc} / \mathrm{MeOH}$. A total of 241 fractions of $500 \mathrm{~mL}$ each were obtained. Fractions were analyzed by TLC under UV light and stained with $\mathrm{Ce}\left(\mathrm{SO}_{4}\right)_{2}$, and then pooled according to their similarity into 19 fractions (A to S). From fraction A ( $248.7 \mathrm{mg}$, hexane 100\%), a white solid (206.2 $\mathrm{mg}, 0.0104 \%$ ) precipitated, which was washed in cold Hex and dried in vacuo. This solid was soluble in $\mathrm{CHCl}_{3}$ and its mp was $43-45^{\circ} \mathrm{C}$ (HG1). Fraction D (11.095 g, Hex/EtOAc 80:20) was treated with three consecutive CCs on silica gel eluted with different gradients of solvents (Hex/EtOAc, $\left.\mathrm{Hex} / \mathrm{CHCl}_{3} / \mathrm{EtOAc} \mathrm{x} 2\right)$. The last CC yielded $43 \mathrm{sf}$. From sf 32-39 (74.8 mg), a crystalline solid (55 mg, $0.0028 \%$ ) precipitated, which was washed with Hex and dried in vacuo. This solid was named HG2. Fractions F-H (10.1321 g, Hex/EtOAc 50:50-30:70) were passed through a CC on silica gel (400 g) eluted with a gradient of Hex/EtOAc, which yielded 121 sf. From sf 91-110, a yellowish solid (43 mg) crystalized, which was processed through a preparative TLC (Hex/acetone 60:40) recovering $25 \mathrm{mg}$ of yellowish solid. The latter was further purified by CC on silica gel $(2 \mathrm{~g})$ eluted with a gradient of Hex/acetone yielding 103 sf. Sf 80-102 (Hex/acetone 60:40-40:60) yielded a yellowish solid (6.6 mg, $0.0003 \%$ ), soluble in acetone, with a $\mathrm{mp} 213-215^{\circ} \mathrm{C}$, and it was characterized as $p$-coumaric acid (6) [59]. Fractions F-H (Hex/EtOAc 20:80) were also chromatographed on silica gel (400 g) CC eluted with a gradient of DCM/acetone, yielding 141 sf. Sf 33-35 (Hex/EtOAc 85:15) afforded a pink solid (12.4 mg, $0.0006 \%$ ), which was washed with $\mathrm{CHCl}_{3}$. This solid had a temperature between 80 and $82{ }^{\circ} \mathrm{C}$, and was characterized as margaric acid (7) [54]. Fraction I (5.3493 g, EtOAc 100\%) was treated with two consecutive CCs on silica gel eluted with different gradients of solvents (DCM/acetone/MeOH and $\left.\mathrm{CHCl}_{3} / \mathrm{MeOH}\right)$. The last CC yielded $163 \mathrm{sf}$. The sf 73-126 $(16.5 \mathrm{mg})$ was treated with preparative TLC and eluted with $\mathrm{CHCl}_{3} / \mathrm{MeOH}$ (90:10) yielding a green solid (13.5 mg), which was further purified by CC obtaining a green solid ( $3 \mathrm{mg}, 0.0002 \%)$ soluble in methanol, and characterized as caffeic acid (8) [60]. From fraction J (7.4776 g, EtOAc/MeOH 70:30), a white solid (272 mg, 0.0138\%) precipitated, and was washed in $\mathrm{MeOH}$ by sonication until it was pure. Its mp was $>280^{\circ} \mathrm{C}$, and the compound was characterized as daucosterol (eleutheroside A) (9) [58]. Fractions N-S (EtOAc/MeOH 40:60 to MeOH $100 \%$ ) yielded a white crystalline solid $(2.7787 \mathrm{~g}, 0.14 \%)$ soluble in water, which was washed in $\mathrm{MeOH}$ by sonication until it was pure. This compound precipitated from the $\mathrm{CHCl}_{3} / \mathrm{MeOH}$ extract when it was concentrated in vacuo. Its $\mathrm{mp}$ was $>300^{\circ} \mathrm{C}$, and it was characterized by X-ray diffraction (XRD) as potassium chloride $(\mathrm{KCl})(10)[61]$.

\subsection{Acetylation Reactions}

Compounds 5 and 9 ( $25 \mathrm{mg}$ each) were separately dissolved in pyridine $(0.5 \mathrm{~mL})$. Acetic anhydride $(0.5 \mathrm{~mL})$ was added dropwise to the stirring solutions. The reaction mixtures were left stirring overnight at room temperature (r.t.). The reaction crudes were then diluted into EtOAc $(10 \mathrm{~mL})$ and washed four times with a $10 \% \mathrm{HCl}$ solution. The organic fractions were dried with anhydrous sodium sulfate and dried in vacuo to give the acetylated products. The purity of the products was assessed by TLC.

\subsection{Methylation of Oleic Acid}

Compound 4 ( $3.3 \mathrm{mg}$ ) was dissolved in toluene $(0.1 \mathrm{~mL})$. Then $\mathrm{H}_{2} \mathrm{SO}_{4}$ solution in $\mathrm{MeOH}$ was added dropwise to the stirring solution of the fatty acid (FA). The reaction was left stirring for $24 \mathrm{~h}$ at 
$60{ }^{\circ} \mathrm{C}$. The reaction crude was then diluted in EtOAc $(10 \mathrm{~mL})$ and washed three times with $\mathrm{NaCl}(5 \%)$ and one time with $\mathrm{NaHCO}_{3}(5 \%)$ solutions. The organic phase was dried with sodium sulfate and distilled in vacuo to give the methylated product. The purity of the product was assessed by TLC.

\subsection{GC-MS Analysis}

The Hex extract and the solids HG1 and HG2 were analyzed by GC-MS using the following conditions: HP-5MS GC capillary column $(30 \mathrm{~m} \times 0.25 \mathrm{~mm} \times 0.25 \mu \mathrm{m}$ film thickness). Helium was used as carrier gas at a flow rate of $1.0 \mathrm{~mL} / \mathrm{min}$, the ion source and split-less injector temperatures were $230{ }^{\circ} \mathrm{C}$ and $250{ }^{\circ} \mathrm{C}$, respectively, and the injection volume was $1-2 \mu \mathrm{L}$ of a solution of $1 \mathrm{mg} / \mathrm{mL}$ of the extract or isolated compounds in $\mathrm{CHCl}_{3}$. The oven temperature was programmed from $50^{\circ} \mathrm{C}$ to $285^{\circ} \mathrm{C}$ at a ramping rate of $2{ }^{\circ} \mathrm{C} / \mathrm{min}$. The electron ionization energy was set at $70 \mathrm{eV}$, and fragments from 1 to $3000 \mathrm{Da}$ were collected. The identification of the chemical constituents was carried out by comparison of the obtained mass spectra with those stored in the NIST library version 1.7a.

\subsection{UPLC-QTOF-MS Analysis}

The aqueous extract was passed through a ZOBRAX Eclipse Plus C18 HD $2.1 \times 50 \mathrm{~mm}$ and $1.8 \mu \mathrm{m}$ ultra-high performance liquid chromatography (UPLC) column to separate its components. The components of the extract were separated with a gradient of water and $\mathrm{MeOH}$ with a flux of $0.25 \mathrm{~mL} / \mathrm{min}$. The gradient started with $30 \%$ methanol and reached $100 \%$ of this solvent in $6 \mathrm{~min}$, and kept this percentage for $4 \mathrm{~min}$. Then, the gradient went back to $30 \% \mathrm{MeOH}$ in $1 \mathrm{~min}$. The detector was set in a positive mode in the range of acquisition between 100 and $3000 \mathrm{~m} / \mathrm{z}$. The difference of potential at the source was $3000 \mathrm{~V}$, while the fragmentor voltage was $175 \mathrm{~V}$. Data was extracted by molecular features. Metabolites were tentatively identified with the databases FooDB, ReSpect, PhytoHub, and Plant Metabolic Network (PMN and by comparison with the literature.

\subsection{Bacterial Strains}

The tested bacteria include nine resistant strains isolated in the University Hospital of the Universidad Autonoma de Nuevo León (Monterrey, Nuevo León, Mexico). The Gram-positive bacteria were: methicillin-resistant Staphylococcus aureus (14-2095), linezolid-resistant S. epidermidis (14-583), and vancomycin-resistant Enterococcus faecium (10-984). The Gram-negative bacteria were: carbapenem-resistant Acinetobacter baumannii (12-666), extended spectrum $\beta$-lactamase (ESBL) Escherichia coli (14-2081), carbapenem-resistant Pseudomonas aeruginosa (13-1391), oxacillin-resistant (OXA-48) Klebsiella pneumoniae, ESBL K. pneumoniae (17-1692), and New Delhi metallo- $\beta$-lactamase 1 (NDM-1+) K. pneumoniae (14-3335).

\subsection{Antibacterial Activity}

The minimum inhibitory concentration (MIC) of the extracts, fractions, and pure compounds were determined in duplicate by the micro-dilution broth method in 96-well microplates [62]. The aqueous extract was dissolved in distilled water, while organic extracts and pure compounds were dissolved in dimethyl sulfoxide (DMSO). The solutions were then diluted in Mueller-Hinton broth (Difco, Detroit, MI, USA), in order to achieve concentrations ranging from 500 to $7.81 \mu \mathrm{g} / \mathrm{mL}$ for extracts and 200 to $3.125 \mu \mathrm{g} / \mathrm{mL}$ for pure compounds. The range of concentrations used for dimethyl sulfoxide (DMSO) was from $6 \%$ to $0.1 \%(v / v)$ and this solution was used as a negative control. The inoculum was adjusted to a concentration of $5 \times 10^{5} \mathrm{CFU} / \mathrm{mL}$, according to the National Committee for Clinical Laboratory Standard (NCCLS) guidelines (CLSI, 2015). Levofloxacin was used as a positive control for resistant strains and its concentrations ranged between 200 and $3.125 \mu \mathrm{g} / \mathrm{mL}$. Controls of sterility of the extracts, control of the inoculum, and control of the DMSO were performed. The 96-well microplates were sealed and incubated aerobically at $37^{\circ} \mathrm{C}$ for $24 \mathrm{~h}$ with the exception of S. epidermidis, which was incubated for $48 \mathrm{~h}$. After the incubation, the turbidity or bottom deposition was visually evaluated to 
determine the microorganism viability. The MIC values were determined as the lowest concentration of extracts or pure compounds able to inhibit the microorganism growth.

\section{Conclusions}

This is the first report of secondary metabolites of H. glomerata and is the first in the genus Hechtia. There is a need for bioassay guided studies of this plant with sensitive bacteria in order to explain its use in Mexican traditional medicine. Additionally, it is necessary to isolate the active compounds from Hex and aqueous extracts to identify a good candidate for treating resistant bacterial infections.

Author Contributions: T.S. prepared the extracts, isolated, characterized, evaluated the phytochemicals, and wrote the manuscript. E.G.-G. supervised the antibacterial assays. V.M.R.-G. performed the N.M.R. experiments. T.S. and M.Y.R. identified the constituents of the aqueous extract by UPLC-MS-QTOF. L.A. carried out G.C.-M.S. analysis. M.d.R.C.-C. contributed to the design and supervision of this project. All authors took part in the critical reading of the manuscript.

Funding: This research did not receive any specific grant from funding agencies in the public, commercial, or not-for-profit sectors.

Acknowledgments: The manuscript was taken in part from the PhD thesis of TS. TS thanks CONACYT-Mexico for the scholarship (621143) to carry out his PhD studies. We thank the biologist Mauricio Gonzalez-Ferrara for the identification and collection of the plant and Garza-Tovar L.L. for the X-Ray analysis of the inorganic compound. We thank Sam Williams for improving the spelling and grammar of the manuscript.

Conflicts of Interest: All authors declare they have no actual or potential conflict of interest.

\section{References}

1. Cox, E.; Nambiar, S.; Baden, L. Needed: Antimicrobial Development. N. Engl. J. Med. 2019, 380, 783-785. [CrossRef] [PubMed]

2. Aslam, B.; Wang, W.; Arshad, M.I.; Khurshid, M.; Muzammil, S.; Rasool, M.H.; Nisar, M.A.; Alvi, R.F.; Aslam, M.A.; Qamar, M.U.; et al. Antibiotic resistance: A rundown of a global crisis. Infect. Drug Resist. 2018, 11, 1645-1658. [CrossRef] [PubMed]

3. Abat, C.; Raoult, D.; Rolain, J.-M. Are we living in an antibiotic resistance nightmare? Clin. Microbiol. Infect. 2018, 24, 568-569. [CrossRef] [PubMed]

4. Tacconelli, E.; Carrara, E.; Savoldi, A.; Harbarth, S.; Mendelson, M.; Monnet, D.L.; Pulcini, C.; Kahlmeter, G.; Kluytmans, J.; Carmeli, Y.; et al. Discovery, research, and development of new antibiotics: The WHO priority list of antibiotic-resistant bacteria and tuberculosis. Lancet Infect. Dis. 2018, 18, 318-327. [CrossRef]

5. Newman, D.J.; Cragg, G.M. Natural Products as Sources of New Drugs from 1981 to 2014. J. Nat. Prod. 2016, 79, 629-661. [CrossRef] [PubMed]

6. Alonso-Castro, A.J.; Villarreal, M.L.; Salazar-Olivo, L.A.; Gomez-Sanchez, M.; Dominguez, F.; Garcia-Carranca, A. Mexican medicinal plants used for cancer treatment: Pharmacological, phytochemical and ethnobotanical studies. J. Ethnopharmacol. 2011, 133, 945-972. [CrossRef] [PubMed]

7. Juárez-Vázquez, M.D.C.; Carranza-Álvarez, C.; Alonso-Castro, A.J.; González-Alcaraz, V.F.; Bravo-Acevedo, E.; Chamarro-Tinajero, F.J; Solano, E. Ethnobotany of medicinal plants used in Xalpatlahuac, Guerrero, México. J. Ethnopharmacol. 2013, 148, 521-527. [CrossRef] [PubMed]

8. Espejo-Serna, A.; López-Ferrari, A.R.; Ramírez-Morillo, I. Bromeliaceae. Flora del Bajío y Reg. Adyacentes 2009, 165,145 .

9. Burt-Utley, K.; Utley, J.F.; García-Mendoza, A. Contributions toward a revision of Hechtia (Bromeliaceae, Pitcairnioideae). I. New and noteworthy species of Hechtia from Mexico. Phytoneuron 2011, 59, 1-17.

10. Villaseñor, J.L. Checklist of the native vascular plants of Mexico. Rev. Mex. Biodivers. 2016, 87, 559-902. [CrossRef]

11. Santana, C.; de Oliveira-Júnior, R.; Araújo, C.; Souza, G.; de Lima-Saraiva, S.; Guimarães, A.; da Silva Almeida, J. Phytochemical Screening, Antioxidant and Antibacterial Activity of Encholirium spectabile (Bromeliaceae). Int. J. Sci. 2012, 11, 1-19.

12. De Lima-Saraiva, S.R.G.; Silva, J.C.; Branco, C.R.C.; Branco, A.; Cavalcanti Amorim, E.L.; da Silva Almeida, J.R.G. Antinociceptive effect of Encholirium spectabile: A Bromeliaceae from the Brazilian caatinga biome. Pharmacogn. Mag. 2014, 10, S655-S660. [PubMed] 
13. De Oliveira-Júnior, R.G.; Ferraz, C.A.A.; Souza, G.R.; Guimarães, A.L.; de Oliveira, A.P.; de Lima-Saraiva, S.R.G.; Rolim, L.A.; Rolim-Neto, P.J.; da Silva Almeida, J.R.G. Phytochemical analysis and evaluation of antioxidant and photoprotective activities of extracts from flowers of Bromelia laciniosa (Bromeliaceae). Biotechnol. Biotechnol. Equip. 2017, 31, 600-605. [CrossRef]

14. Oliveira-Junior, R.G.; Souza, G.R.; Guimarães, A.L.; Oliveira, A.P.; Araújo, C.S.; Silva, J.C.; Castro, R.N. Photoprotective, antibacterial activity and determination of phenolic compounds of Neoglaziovia variegata (Bromeliaceae) by high performance liquid chromatography-diode array detector (HPLC-DAD) analysis. Afr. J. Pharm. Pharmacol. 2015, 9, 576-584.

15. Pío-León, J.F.; López-Angulo, G.; Paredes-López, O.; de Jesús Uribe-Beltrán, M.; Díaz-Camacho, S.P.; Delgado-Vargas, F. Physicochemical, Nutritional and Antibacterial Characteristics of the Fruit of Bromelia pinguin L. Plant Foods Hum. Nutr. 2009, 64, 181. [CrossRef] [PubMed]

16. Romano, B.; Fasolino, I.; Pagano, E.; Capasso, R.; Pace, S.; De Rosa, G.; Milic, N.; Orlando, P.; Izzo, A.A.; Borrelli, F. The chemopreventive action of bromelain, from pineapple stem (Ananas comosus L.), on colon carcinogenesis is related to antiproliferative and proapoptotic effects. Mol. Nutr. Food Res. 2014, 58, 457-465. [CrossRef]

17. Juvik, J.O.; Holmelid, B.; Francis, W.G.; Lie Andersen, H.; De Oliveira, P.A.; Gonçalves de Oliveira Júnior, R.; Guedes da Silva Almeida, R.J.; Fossen, T. Non-Polar Natural Products from Bromelia laciniosa, Neoglaziovia variegata and Encholirium spectabile (Bromeliaceae). Molecules 2017, 22, 1478. [CrossRef]

18. Steingass, C.B.; Glock, M.P.; Schweiggert, R.M.; Carle, R. Studies into the phenolic patterns of different tissues of pineapple (Ananas comosus L. Merr.) infructescence by HPLC-DAD-ESI-MSnand GC-MS analysis. Anal. Bioanal. Chem. 2015, 407, 6463-6479. [CrossRef]

19. Altamirano, F. Memorial terapéutico de plantas Mexicanas; Imprenta del Gobierno Federal, en el ex-Arzobispado: Ciudad de México, Mexico, 1896; pp. 310-326.

20. Eguiarte, L.E. Cactáceas y otras plantas nativas de la Cañada, Cuicatlán, Oaxaca. Cactáceas y Suculentas México 2005, 77, 152. [CrossRef]

21. Hornung-Leoni, C.T. Avances sobre Usos Etnobotánicos de las Bromeliaceae en Latinoamérica. Boletin Latinoamericano y del Caribe de plantas Medicinales y Aromaticas 2011, 10, 297-314.

22. Sandoval-Bucio, E.N.; Flores-Cruz, M.; Martinez-Bernal, A. Useful Bromeliads from Mexico. Cactáceas y Suculentas Mex. 2004, 49, 100-115.

23. Fernández, V.; Guzmán-Delgado, P.; Graça, J.; Santos, S.; Gil, L. Cuticle Structure in Relation to Chemical Composition: Re-Assessing the Prevailing Model. Front. Plant Sci. 2016, 7, 427. [CrossRef] [PubMed]

24. Yeats, T.H.; Rose, J.K.C. The formation and function of plant cuticles. Plant Physiol. 2013, 163, 5-20. [CrossRef] [PubMed]

25. Ogburn, R.M.; Edwards, E.J. Chapter 4-The Ecological Water-Use Strategies of Succulent Plants. In Advances in Botanical Research; Kader, J.-C., Delseny, M., Eds.; Academic Press: Waltham, MA, USA, 2010; pp. 179-225. ISBN 0065-2296.

26. Lewis, N.G. Plant phenolics. In Antioxidants in Higher Plants; CRC Press: Boca Raton, FL, USA, 2017; pp. $135-169$.

27. Macoy, D.M.; Kim, W.Y.; Lee, S.Y.; Kim, M.G. Biosynthesis, physiology, and functions of hydroxycinnamic acid amides in plants. Plant Biotechnol. Rep. 2015, 9, 269-278. [CrossRef]

28. Wildt, J.; Kobel, K.; Schuh-Thomas, G.; Heiden, A.C. Emissions of Oxygenated Volatile Organic Compounds from Plants Part II: Emissions of Saturated Aldehydes. J. Atmos. Chem. 2003, 45, 173-196. [CrossRef]

29. Kunst, L.; Samuels, L. Plant cuticles shine: Advances in wax biosynthesis and export. Curr. Opin. Plant Biol. 2009, 12, 721-727. [CrossRef] [PubMed]

30. Qi, X.-L.; Zhang, Y.-Y.; Zhao, P.; Zhou, L.; Wang, X.-B.; Huang, X.-X.; Lin, B.; Song, S.-J. Ent-Kaurane Diterpenoids with Neuroprotective Properties from Corn Silk (Zea mays). J. Nat. Prod. 2018, 81, 1225-1234. [CrossRef]

31. Piironen, V.; Lindsay, D.G.; Miettinen, T.A.; Toivo, J.; Lampi, A.M. Plant sterols: Biosynthesis, biological function and their importance to human nutrition. J. Sci. Food Agric. 2000, 80, 939-966. [CrossRef]

32. González-Salvatierra, C.; Andrade, J.L.; Escalante-Erosa, F.; García-Sosa, K.; Peña-Rodríguez, L.M. Antioxidant content in two CAM bromeliad species as a response to seasonal light changes in a tropical dry deciduous forest. J. Plant Physiol. 2010, 167, 792-799. [CrossRef]

33. Manetti, L.M.; Deiaporte, R.H.; Laverde, A. Metabólitos secundários da família Bromeliaceae. Quim. Nova 2009, 32, 1885-1897. [CrossRef] 
34. Okamura, N.; Hine, N.; Harada, S.; Fujioka, T.; Mihashi, K.; Yagi, A. Three chromone components from Aloe vera leaves. Phytochemistry 1996, 43, 495-498. [CrossRef]

35. Wu, X.; Yin, S.; Zhong, J.; Ding, W.; Wan, J.; Xie, Z. Mushroom tyrosinase inhibitors from Aloe barbadensis Miller. Fitoterapia 2012, 83, 1706-1711. [CrossRef] [PubMed]

36. Zheng, C.J.; Yoo, J.-S.; Lee, T.-G.; Cho, H.-Y.; Kim, Y.-H.; Kim, W.-G. Fatty acid synthesis is a target for antibacterial activity of unsaturated fatty acids. FEBS Lett. 2005, 579, 5157-5162. [CrossRef] [PubMed]

37. Pejin, B.; Savic, A.; Sokovic, M.; Glamoclija, J.; Ciric, A. In vitro evaluation of antiradical and antimicrobial activities of phytol. Nat. Prod. Res. 2014, 28, 372-376. [CrossRef] [PubMed]

38. Pejin, B.; Ciric, A.; Glamoclija, J.; Nikolic, M.; Sokovic, M. In vitro anti-quorum sensing activity of phytol. Nat. Prod. Res. 2015, 29, 374-377. [CrossRef] [PubMed]

39. Bączek, K.B.; Kosakowska, O.; Przybył, J.L.; Pióro-Jabrucka, E.; Costa, R.; Mondello, L.; Gniewosz, M.; Synowiec, A.; Wegglarz, Z. Antibacterial and antioxidant activity of essential oils and extracts from costmary (Tanacetum balsamita L.) and tansy (Tanacetum vulgare L.). Ind. Crops Prod. 2017, 102, 154-163. [CrossRef]

40. Veneziani, R.C.S.; Ambrósio, S.R.; Martins, C.H.G.; Lemes, D.C.; Oliveira, L.C. Chapter 4-Antibacterial Potential of Diterpenoids. In Studies in Natural Products Chemistry; Atta-ur-Rahman, B.T.-S., Ed.; Elsevier: Amsterdam, Netherlands, 2017; pp. 109-139. ISBN 1572-5995.

41. Sharma, R.K. Phytosterols: Wide-spectrum antibacterial agents. Bioorg. Chem. 1993, 21, 49-60. [CrossRef]

42. Cho, E.J.; Choi, J.Y.; Lee, K.H.; Lee, S. Isolation of Antibacterial Compounds from Parasenecio pseudotaimingasa. Hort. Environ. Biotechnol. 2012, 53, 561-564. [CrossRef]

43. Xie, Y.; Yang, W.; Tang, F.; Chen, X.; Ren, L. Antibacterial activities of flavonoids: Structure-activity relationship and mechanism. Curr. Med. Chem. 2015, 22, 132-149. [CrossRef]

44. Toudert, N.; Djilani, S.E.; Djilani, A. Antimicrobial activity of flavonoids of Ampelodesma mauritanica. Am. J. Sustain. Agric. 2009, 3, 227-228.

45. Avato, P.; Bucci, R.; Tava, A.; Vitali, C.; Rosato, A.; Bialy, Z.; Jurzysta, M. Antimicrobial activity of saponins from Medicago sp.: Structure-activity relationship. Phyther. Res. 2006, 20, 454-457. [CrossRef] [PubMed]

46. Lunga, P.K.; Qin, X.-J.; Yang, X.W.; Kuiate, J.-R.; Du, Z.Z.; Gatsing, D. Antimicrobial steroidal saponin and oleanane-type triterpenoid saponins from Paullinia pinnata. BMC Complement. Altern. Med. 2014, 14, 369. [CrossRef] [PubMed]

47. Albert, S.; Horbach, R.; Deising, H.B.; Siewert, B.; Csuk, R. Synthesis and antimicrobial activity of (E) stilbene derivatives. Bioorg. Med. Chem. 2011, 19, 5155-5166. [CrossRef] [PubMed]

48. Ma, D.S.L.; Tan, L.T.; Chan, K.; Yap, W.H.; Lee, L. Resveratrol-Potential Antibacterial Agent against Foodborne Pathogens. Front. Pharmacol. 2018, 9, 1-16. [CrossRef] [PubMed]

49. Paulo, L.; Ferreira, S.; Gallardo, E.; Queiroz, J.A.; Domingues, F. Antimicrobial activity and effects of resveratrol on human pathogenic bacteria. World J. Microbiol. Biotechnol. 2010, 26, 1533-1538. [CrossRef]

50. Ogungbamila, F.O.; Onawunmi, G.O.; Ibewuike, J.C.; Funmilayo, K.A. Antibacterial Constituents of Ficus barteri Fruits. Int. J. Pharmacogn. 1997, 35, 185-189. [CrossRef]

51. Tao, R.; Wang, C.-Z.; Kong, Z.-W. Antibacterial/Antifungal Activity and Synergistic Interactions between Polyprenols and Other Lipids Isolated from Ginkgo biloba L. Leaves. Molecules 2013, 18, 2166-2182. [CrossRef] [PubMed]

52. Lou, Z.; Wang, H.; Rao, S.; Sun, J.; Ma, C.; Li, J. p-Coumaric acid kills bacteria through dual damage mechanisms. Food Control 2012, 25, 550-554. [CrossRef]

53. Pei, K.; Ou, J.; Huang, J.; Ou, S. p-Coumaric acid and its conjugates: Dietary sources, pharmacokinetic properties and biological activities. J. Sci. Food Agric. 2016, 96, 2952-2962. [CrossRef]

54. Saito, T.; Yamaji, T.; Hayamizu, K.; Yanagisawa, M.; Yamamoto, O.; Matsuyama, S.; Wasada, N.; Someno, K.; Kinugasa, S.; Tamura, T.; et al. SDBS. Available online: https://sdbs.db.aist.go.jp (accessed on 26 February 2019).

55. Del Río, J.C.; Marques, G.; Rodríguez, I.M.; Gutiérrez, A. Chemical composition of lipophilic extractives from jute (Corchorus capsularis) fibers used for manufacturing of high-quality paper pulps. Ind. Crops Prod. 2009, 30, 241-249. [CrossRef]

56. Gade, S.; Rajamanikyam, M.; Vadlapudi, V.; Nukala, K.M.; Aluvala, R.; Giddigari, C.; Karanam, N.J.; Barua, N.C.; Pandey, R.; Upadhyayula, V.S.V.; et al. Acetylcholinesterase inhibitory activity of stigmasterol \& hexacosanol is responsible for larvicidal and repellent properties of Chromolaena odorata. Biochim. Biophys. Acta Gen. Subj. 2017, 1861, 541-550. [PubMed] 
57. Kerwin, J.L.; Wiens, A.M.; Ericsson, L.H. Identification of fatty acids by electrospray mass spectrometry and tandem mass spectrometry. J. Mass Spectrom. 1996, 31, 184-192. [CrossRef]

58. Kojima, H.; Sato, N.; Hatan, A.; Ogura, H. Sterol glucosides from Prunella vulgaris. Phytochemistry 1990, 29, 2351-2355. [CrossRef]

59. Karthikeyan, R.; Devadasu, C.; Srinivasa Babu, P. Isolation, Characterization, and RP-HPLC Estimation of P-Coumaric Acid from Methanolic Extract of Durva Grass (Cynodon dactylon Linn.) (Pers.). Int. J. Anal. Chem. 2015, 2015, 201386. [CrossRef]

60. De Falco, B.; Incerti, G.; Bochicchio, R.; Phillips, T.D.; Amato, M.; Lanzotti, V. Metabolomic analysis of Salvia hispanica seeds using NMR spectroscopy and multivariate data analysis. Ind. Crops Prod. 2017, 99, 86-96. [CrossRef]

61. Moroyoqui-Estrella, G.; Pérez-Salas, R.; Rodríguez-Mijangos, R. A generalized rule of average for glow peak temperature of ternary alkali halide systems. Rev. Mex. Fis. 2011, 57, 154-157.

62. Bocanegra-García, V.; Del Rayo Camacho-Corona, M.; Ramírez-Cabrera, M.; Rivera, G.; Garza-González, E. The bioactivity of plant extracts against representative bacterial pathogens of the lower respiratory tract. BMC Res. Notes 2009, 2, 95. [CrossRef] [PubMed]

Sample Availability: Samples of the compounds are available from the authors. 